Man and Nature

L'homme et la nature

\title{
Conversations Containing Truth: Dialogues with Berkeley's Lying God
}

\section{Kevin L. Cope}

Volume 9, 1990

URI : https://id.erudit.org/iderudit/1012609ar

DOI : https://doi.org/10.7202/1012609ar

Aller au sommaire du numéro

Éditeur(s)

Canadian Society for Eighteenth-Century Studies / Société canadienne d'étude du dix-huitième siècle

ISSN

0824-3298 (imprimé)

1927-8810 (numérique)

Découvrir la revue

Citer cet article

Cope, K. L. (1990). Conversations Containing Truth: Dialogues with Berkeley's Lying God. Man and Nature / L'homme et la nature, 9, 45-55.

https://doi.org/10.7202/1012609ar

Copyright (C Canadian Society for Eighteenth-Century Studies / Sociéte canadienne d'étude du dix-huitième siècle, 1990
Ce document est protégé par la loi sur le droit d'auteur. L'utilisation des services d'Érudit (y compris la reproduction) est assujettie à sa politique d'utilisation que vous pouvez consulter en ligne.

https://apropos.erudit.org/fr/usagers/politique-dutilisation/ 


\section{Conversations Containing Truth: Dialogues with Berkeley's Lying God}

Berkeley's philosophy could well be called 'experiential' rather than 'empirical.' Like most of his 'empiricist' colleagues, Berkeley wants to draw evidence from experience, but he also concerns himself with the experience of philosophizing. Berkeley is, consequently, acutely concerned with the literary experience of his theories. Although Berkeley's canon contains more monologues, dialogues, aphorisms, poems, and polemics than it does traditional philosophical disquisitions, the examination of Berkeley as a writer is a recent and forthcoming phenomenon. Important early essays on Berkeley's style, pose, and argumentative technique - those, for example, of Kathleen Raine, John Linell, Donald Davie, and Stephen Leo Carr - remained on the margins of Berkeleian studies until the advent, in 1983, of John Richetti's Philosophical Writing. Forthcoming works by Peter Walmsley, Mark Box, and the present author will extend the temporal and conceptual range of Richetti's pioneering efforts, making the study of philosophical discourse a central topic in the fourth century of Berkeley criticism. ${ }^{1}$

Philosophers like Shaftesbury or Hume, of course, make use of literary genres, but Berkeley goes further than any of his colleagues. For Berkeley, the literary experience of philosophy not only enlivens, but culminates and eventually replaces his philosophical project. Berkeley's dialogue, Alciphron: Or, the Minute Philosopher, exemplifies Berkeley's quest for a philosophy which presents itself in both a systematic and experiential way, for a philosophy which, as Berkeley says, is both 'comprehensive' and 'compendious.' Alciphron lays out a program for enclosing a comprehensive philosophy - and, indeed, philosophy itself - in the compendious, episodic conversation of literary gentlemen. Berkeley's dialogue shows how a potentially unending process, like philosophical conversation, may generate a sense of completeness similar to that produced by the comprehending of a philosophical system. It will be my project to show how Berkeley's literary philosophizing leads him to affirm one of the strangest of philosophical theses: that the infinite, comprehending God, the 'Author of Nature,' can best be understood when he is completely contained 
in his own literariness - when, in other words, He is known in His ability to imitate, distort, and even deceive.

A desire for 'compendiousness,' for the comprehension of a vast philosophical lore in a small literary space, permeates all of Berkeley's writing. Berkeley's first effort at dialogue, Three Dialogues Between Hylas and Philonous, aims to 'render the sciences compendious,' to treat this biggest of topics in three short discussions. Berkeley's projects for social reform take a similar approach. Berkeley planned, for example, to educate the vast new world from a small college in Bermuda. Berkeley's interest in an expansive compactness manifests itself in his treatment of moral as well as sociological or theoretical matters. In his 'Advertisement' to Alciphron, Berkeley projects a consideration of 'the free-thinker in the various lights of atheist, libertine, enthusiast, scorner, critic, metaphysician, fatalist, and sceptic' even though 'it must not be imagined that every one of these characters agrees with every individual free-thinker.' He plans to characterize whole philosophical systems by consolidating them in one caricature, that of Alciphron, the free-thinker. The fact that many of Alciphron's alleged attributes contradict one another is precisely Berkeley's point. Although rational philosophy can make little sense of such a mixed bag of characteristics, language and literature have no trouble in bringing widely disparate attributes into compendious lists. By enclosing philosophical systems in literary devices like 'characters,' Berkeley can thus confirm the prejudice-inducing lessons of 'experience,' for he can condense an unintelligible array of contrary characteristics into a small set of intelligible stereotypes.

Berkeley brings to life the comprehending power of his rhetoric by affecting a novelistic mannerism, the naming his works after the individual persons. Rather than $A$ Theory of Libertinism he gives us Alciphron. The resulting contrast between Berkeley's individual spokesmen and Berkeley's globalizing theories implies that another story lies behind the philosophical tale that is being told. Berkeley is working out the relation of the individual person to his universalizing philosophy and of his universalizing philosophy to that 'experience' - that dialogue - in which his philosophy must be contained. Berkeley drives home his point by setting Alciphron in distant Rhode Island - in a 'distant retreat' in a 'remote corner of the country'. 'far beyond the verge of ... the world.' This displacement of the dialogue to the outer limits - to the boundary between real and fictional places - reiterates the displacement of the individual philosopher from the comprehensive, objective philosophy that Berkeley would write. Berkeley writes from the margin of civilization in the hope of comprehending his civilizing philosophy.

Berkeley's writing thus deals in a surprisingly literal way with the enclosure of philosophy. It is less concerned with what is contained in 
philosophy than with the act of containment and even with the container. Alciphron, Berkeley's title declares, will 'contain' 'An APOLOGY for the CHRISTIAN RELIGION, against those who are called FREE THINKERS.' Alciphron will 'contain' rather than deliver a polemic; it will, additionally, contain a story about those uncontainable forces, the free-thinkers. Berkeley's literary dialogue, moreover, will contain philosophy by means of being contained in a literary container. Contained within seven creative days, Berkeley's philosophical Genesis implicitly contains a history of everything that could be known. Crito's house, where this all-containing dialogue will take place, appropriately stands at both the center and the rim of several containers.

After dinner we took our walk to Crito's, which lay through half-a-dozen pleasant fields planted round with plane trees, that are very common in this part of the country. We walked under the delicious shade of these trees for about an hour before we came to Crito's house, which stands in the middle of a small park, beautified with two fine groves of oak and walnut, and a winding stream of clear water. We met a servant at the door with a small basket of fruit, which he was carrying into a grove, where he said his master was with two strangers. We found them all sitting under a shade. And after the usual forms at first meeting, Euphranor and I sat down by them. (33)

At the end of a series of enclosed fields, shady groves, and treesurrounded walkways, Crito's home is both the center and the end of a series of containers. Yet Crito's house is no prison-house of language. Nor is it bounded by an inescapable horizon. It may be contained by Berkeley's allegorical setting, but it also contains Berkeley, Berkeley's conversants, and the setting that they define.

Situated in a pleasantly shady hyperspace, Crito's house is the ultimate container. It contains the idea of containment. As a result, it also contains the idea of the escape from containment. While visiting Crito's domicile, Berkeley's conversants take some terrifying excursions. On most days, these gentlemen converse over the tea-table. On the second day of their debate, however, they walk to a sublime shore strewn with 'wild broken rocks' (65). On the fifth day, the tea room opens up into a boulevard of cultivated limes. Following this enclosed walkway, the philosophers proceed up to the top of a mountain. At the summit, on the verge of infinity, they find themselves surrounded by both an unbounded 'ocean' and a bounded 'bay.' This bay, in turn, is 'enclosed' by - alternately - craggy, sublime rocks and neatly bordered farmlands. Wavering between contained spaces and uncontained ones, Alciphron is thus 'set' in the encounter between containment and expansion. It is, accordingly, a book full of boundaries. Crito, for example, may live 
in an enclosure, but he remains a man of borders. He defines his surrounding domestic space with reference to a complex of lines. Crisscrossed with tree-lined walkways - straight paths which lead off into the wild and then back to philosophical home - Crito's homeland reconciles circularity with linearity and marginality with containment. His guests may wander afar and dispute widely scattered topics, yet they walk back and forth over the same philosophical routes and always circle back to the tea-table.

It is no exaggeration to say that all of Berkeley's philosophy invokes this paradoxical notion of linear progress through enclosed spaces. Beginning with The New Theory of Vision, Berkeley argues that the idea of a distant object encloses the idea of distance. The 'perception' of a distant object includes a 'perception' of the effort needed to travel to that object. The imaginary line extending from the viewer to the object is enclosed in the three-dimensional idea of the object. The conversants in Alciphron thus see their various destinations in the context of a grid of linear paths. They wear epistemological blinkers which keep their eyes on the route between their perceptions. The same might be said with regard to the theories discussed and to the conversants discussing them. By affiliating different philosophical theories with differentiated persons, Berkeley includes the idea of their distant philosophical relations in their individuality and separateness. He lets the reader literally see the philosophical distance between them.

Perceptions like the perception of distance also contain ideas related to history. An idea of an object suggests that that object stands at a specific distance from the viewer because similar ideas have made similar (and accurate) suggestions in the past. Berkeley thus calls 'distance' a 'mediate' idea. 'Mediate' ideas, like those of distance, are the ideas in which immediate experience makes reference to some other, no longer (or not yet) immediate experience. Mediate ideas may extend perceptions into the future as well as into the past. The idea of a distant object may 'suggest' a plan for eventually reaching and using it. Berkeleian perception is thus always expanding into history. It appears in present time, makes reference to past time, and charts a course of future action. Berkeleian experience contains the experience of a paradox: percipients 'see' a history, both past and future, for immediate perceptions. They 'see' the mediacy of the immediate.

In Alciphron, such immediately mediated perceptions underwrite Berkeley's 'Language of Nature.' This 'language' of 'light and colours' is 'adapted to suggest and exhibit to us the distances, figures, situations, dimensions, and various qualities of tangible objects' 'just as words suggest the things signified by them' (154). The perception of nature is the reading of nature, the immediate deciphering of a code which, 
among other things, suggests that 'objects' stand at a distance. Berkeley, of course, doesn't believe in the existence of a physical space. Instead, he defines space in terms of the time and effort needed to reach a 'tangible' object. 'One mile' means the experience of walking 1,000 paces. As is always the case in Berkeley's enclosed universe, compactness, compendiousness, and value coincide. The best space is that space which is stuffed full of moral and practical precepts. Berkeley, for example, is a great admirer of maxims and aphorisms. He esteems his characters according to the skill with which they pack voluminous things into compact verbal expressions. Crito wins praise for compacting into 'three words' 'the true cause of ruin to those (ancient) states' (76) - unlike Alciphron, who, persuaded that 'the most valuable improvements came latest' in history (39), expels the lessons of history from the empty space of modern philosophy. Crito, in fact, offers not 'three words' but a whole paragraph. Yet Berkeley shows his support for Crito by insisting that Crito's sweeping assertions produce the same rhetorical and philosophical effects as might a pithy phrase or two.

Berkeley's feeling for the immediacy of history sustains his projcet to affiliate philosophy with the imitative arts. Berkeleian perceptions are, in effect, imitations of themselves. They contain both immediate and mediate, original and reflective components. Every perception presents possible histories of that object. I say 'present' rather than 'represent' because the ideas of these actions appear within the idea of an object. Ideas contain rather than refer to the history of their referents. Still, there is no getting around the fact that one does not 'see' these suggested, mediate ideas in quite the same way that one sees objects. In Berkeley's Language of Nature, one might say, every perception carries out a dialogue with its percipient about the completion and representation of its own idea. Ideas invite responses, actions, and commentaries from their percipients; ideas, in other words, call for actions which will transform them into new ideas. Hence my use of 'selfimitation' to designate 'objects' which show within themselves what they eventually will be doing and what we will be doing with them.

The best of all languages, the Language of Nature, could thus be described as a language of intrinsic distortion. It is not a language suited to a deconstructionist discourse in which a sign never quite reveals its signified. It is, rather, a relevatory discourse, a discourse in which a signified thing modifies itself along with that language that describes it. The Language of Nature 'hath a necessary connexion with knowledge, wisdom, and goodness' and 'is equivalent to a constant creation' (159). It is the creation of a new, moralized meaning, a meaning which is, eventually, part of the 'objects' perceived, An 'instantaneous production and reproduction of so many signs' (159), the Language of Nature could 
thus also be described as a language of constructive distortion. It is a language which means more and more rather than less and less, a language which moves further and further away from an object only to infuse that object with new meanings.

Berkeley's philosophy may thus make a full, dialogic use of an adversarial and habitually erring character like Alciphron. By containing the free-thinkers' amphibian theories in a single person, Alciphron, Berkeley can perceive 'him' and thus constructively distort his erring 'philosophy.' He can allow the language of ideas to talk this free-thinker into the image of a Christian philosopher. Such a transformation happens, at least temporarily, at several points; Alciphron is always on the edge of being converted to Berkeley's special version of Christianity (e.g., 208, 264). Dialogue for Berkeley is thus the proper language for a history of philosophy. Dialogue contains dichotomies; rather than pitting philosophical theories against one another in clear-cut, categorical dichotomies, dialogue distorts them into related, if temporally and conceptually distant, historical phenomena.

Berkeleian history itself is a process of constructive distortion. Consider, for example, Berkeley's defense of Moses's account of creation (258 ff.). How can Berkeley talk about a 'beginning' when no one was there to perceive it? It is, however, the very inaccessibility of this terminal point that verifies Berkeley's theories. The beginning was only a point, a kind of tangible premise, from which the process of constructive distortion, the building of a meaningful universe, might begin. Berkeley, for example, advances the extraordinary notion that 'civil and historical proofs' verify what Moses has to say. Berkeley certainly doesn't imagine that bureaucrats, historians, and attorneys were taking notes during the creation. He only wants to suggest that the historical, derrière-garde account of creation has formed and reformed history and history's meaning - that the experience of historical distortion can be constructive. At the other end of creation, the concluding seventh dialogue, Berkeley arrives at yet another invisible idea, the mysterious idea of the Trinity (297). Like the 'beginning,' the Trinity is mentioned only to show that the process of distortion can lead to the construction of valuable, if inexplicable, 'things.' Berkeley 'looks' at this strange idea in order to look back at its formation.

The case is the same with the history of a smaller but equally important construct like that of personal identity. No one has ever perceived, for example, a soul. Yet the perception of a person always implies a long history by which an array of disparate ideas 'suggests' the presence of a conscious being. One of Alciphron's principal errors is his belief that he and his colleagues can 'weed out' 'all such notions or prejudices as were planted in them before they arrived at the free and entire use of 
reason' (39), that they can exclude the history of their own errors from their present, allegedly perfected characters. Psychologically provocative ideas, like that of 'faith,' in turn, lead the soul to reflect on that strange history by which it believes in theories for which there is little evidence - that process by which, as it were, the soul refutes its own ideas! Those persons who are lucky enough to participate in a philosophical dialogue may even hear several versions of the derivation of their faith, whether Lysicles's Swiftian theory that faith rises from delusion or Euphranor's pious belief that faith results from the observation of the ordered universe. Over time, through extended discussion, the mysterious idea of 'faith' may be contained in a constructive dialogue about it. History (and the theories and ideas in it) must thus always progress toward the disclosure of some unexpected, future meaning. When history tells its story, it tells it through ideas - which are no longer part of the past, but are being perceived now and constructively distorted into future meanings.

Berkeley is especially fond of words which signify the complete, teleological transformation, from beginning to end, of nature and natural things. 'Grace' and ' $\mathrm{I}$ ' are Berkeley's favorite examples. The first condenses the story of the transformation of the natural man; the second draws attention to someone who may transform experience. These special words signify the history within the fact of their respective ideas. The word 'number,' of which 'neither you nor I can form distinct simple ideas,' belongs in this privileged category. 'Number,' like 'grace' or 'II' provides a shorthand by which a vast number of ideas, words, and processes may be contained in one 'convenient' term. 'Modern algebra' provides 'a more short, apposite, and artificial sort of language' in which it is 'possible to express by words at length' 'all the steps of the algebraic process' $(293,307)$. Berkeley's special words, words like 'number' or 'grace,' show that language acts on history; indeed, they show that the Language of Nature, meaningful experience, is history. ${ }^{3}$ As history, language moves toward a temporally-displaced end, toward changes that will be completed in future experience. ${ }^{4}$

The suggestive, reformative, and teleological character of language explains the vagueness of some of Berkeley's special terms. Were 'grace' or 'number' or 'I' to make too much sense, were they to terminate too quickly in a specific meaning, the process of constructive distortion might come to a hasty end. Even Berkeley's 'type' characters tend to be indefinite. Most of the action of Alciphron centers on Alciphron, a character who is always willing to change with the dialogue, even if it means softening his own nominal, 'hard-headed' character. Euphranor, who is always ready to listen to a counter-argument, is the second most active character. Crito and Lysicles, stubborn representatives of their positions, 
speak less often. Full-fledged personifications like 'Bubalion' receive nothing but contempt. The fixity of such characters obstructs the transforming process of constructive distortion. Berkeley's is a transforming world; even things which seem to be permanently fixed - say, for example, the defining features of a citrus tree - will take different forms in different environments (57). In the same way, the best character is that character who changes character whenever the medium of characterization, philosophical discourse, moves along.

As the example of the special word 'number' illustrates, Berkeley's formative, teleological language tends toward brevity. The more progressive the language, the more quickly (and distortedly) it presents ideas. Alciphron is perhaps the ultimate study in informative abbreviation, for in this work Berkeley says a great many things by refusing to say anything new. Throughout Alciphron, Berkeley repeats the same antithetical arguments - that virtue promotes the common good and that, as Mandeville claims, vice promotes the common good - over and over again. All of the standard issues from his earlier work - the Molyneux problem (152), the question of identity (155), the linguistic character of experience - reappear without revision. The sheer imitating and repeating of his own work - its re-experience across history is made to suggest that constructive distortion is taking place, that something new is being said. ${ }^{5}$ Berkeley initiates such a constructive falsifying dialogue with himself. He appoints Lysicles, the naughtiest of the conversants, to defend the crypto-atheist Boerhaave (244), then, ten years later, defends this philosopher. ${ }^{6}$ Looking back on the dialogue Alciphron, the author of the monologue Siris will repeat, accept, and constructively distort his own ironical arguments.

A constructive dialogue, a dialogue which comprehends all the possibilities, must confront and contain the destructive capacities of language. The problem with free-thinking is not its falsity, for dialogue exists in order to contain false ideas, but its dis-constructive tendencies, its desire to take apart the social container in which dialogue occurs. Berkeley describes free-thinking not in terms of any free-thinking doctrine, but as a procedure, as a series of steps leading to the dismantling of several useful notions (e.g., 43). Berkeley, however, manipulates the antinomial tendencies of philosophical language. Rather than haggle with the free-thinkers, he turns debate into a series of steps, steps which build a good society and which ultimately enclose the debate itself in that society. He takes 'either/or' arguments and recasts them in the form of contingent propositions. 'If the negatives are not sure, the affirmatives are possible. If the negatives are improbable, the affirmatives are probable' (322). In both of these propositions, the negatives fall in the first half of the conditional, while the affirmatives fall in the latter. The 
negatives, as it were, become a condition of the affirmatives. In Berkeley's literalizing, experiential thinking, the negatives become the historical predecessors of the affirmatives. A counterproductive dichotomy is made to generate, one step at a time, the feeling that an affirmative is being reached.

Language, then, provides Berkeley with a means for commandeering as well as for describing experience. Rather than dividing speakers from referents or alienating words from a transcendental 'Other,' language, as it plays itself out in history, may come to contain beings as big and as knowledgeable as God Himself. 'It is the articulation, combination, variety, copiousness, extensive and general use and easy application of signs (all of which are commonly found in vision) that constitute the true nature of language' (157). The 'true nature of language' is the vigorous use of language, its aggressive deployment to surround unknown things and to quiet quarrels about its meaning. God's excellence, for example, resides in His capacity both to use and to be contained by language. On the one hand, God must abide by a literary stricture like 'decorum'; Christ was born in a barn in order to avoid the vulgar 'éclat' of a palace (247-8). On the other hand, God generates words like 'grace,' words which overturn ordinary usage. The 'copiousness' of language depends on its 'use,' on its authoritative implementation by beings like Berkeley's 'Author of Nature.'

It is through such reasoning that Berkeley comes to a stunning conclusion, that God is most obviously God when He is at his most literary - when He writes, distorts, and even lies. The 'Author of Nature' is never pedantic or punctilious; His style is wild, free, and not overly nice; His texts are magnificent, but not prettily finished (228). God both writes and manipulates nature's language, and He is at his most manipulative when he makes his system of natural signs mean something new or unexpected (158). The apparent bending of a pencil in water, the grotesque images in distorting mirrors, and the irregular reflections in pools of water all exemplify God's ability to expand the boundaries of his own discourse. God literally holds leading conversations with percipients, for he uses his 'language' in so extraordinary a way that it leads percipients to distort common meanings. Berkeley thus boasts that the common-sense meaning of the term 'theological mystery' shows that this term cannot be understood in a commonsensical way (249-9). 'Common sense' becomes the pre-cursor of 'not-socommon sense.' Berkeley argues that the Scriptures must lose the aura of divine authorship after centuries of transmission (239). This fading of the divine aroma must not be taken as an indictment of Scripture, but as a vindication; the fact that the Scriptures no longer seem divine shows that they must have been distorted away from a divine origin. The secularization 
of Scripture is all part of a process by which Berkeley, in tandem with history, comprehends both the sacred and the profane in a 'compendious,' valuably misleading dialogue.

Berkeley thus writes to rather than about infinity. He not only explains but approaches and finally encompasses nature and God. Berkeley's writing is a pre-distorted, precursory image of the writings of an author like Samuel Richardson, who writes to the moment. ${ }^{7}$ Berkeley's is a world in which things and 'words' move toward the expression of something that they might, but have not yet, become. Berkeley's God, appropriately, participates in this motion toward fictionality. His God assumes the guise of Berkeley's own opponents, the deceiving freethinkers - composite characters who, in turn, contain several inconsistent points of view in one character. Berkeley's distorting philosophy thus remains a constructive enterprise - an enterprise which, like his wily God, attempts to anticipate, experience, and comprehend even the most unlikely future interpretations.

KEVIN L. COPE

Louisiana State University

\section{Notes}

1 For a general defense of the literary character of Berkeley's philosophy, see Richetti, pp. 178-182, esp. pp. 164-176. Young, pp. 177-181, argues that Berkeley belongs in a Platonic tradition in which philosophical discourse is more important than the achievement of a philosophical system. Linell, 11-12, discusses the difference in Berkeley between the presentation and the endorsement of ideas. See also Davie, 'Berkeley's style in Siris,' 433; Davie, 'Berkeley and the Style of Dialogue,' passim; Raine, passim; and Carr, 47-60. New books on philosophical literature have recently been published by Peter Walmsley, Kevin L. Cope, and Mark Box: see "Works Cited" below. For a general treatment of the literary reading of philosophical texts, see Ginsberg.

2 Alciphron: Or, the Minute Philosopher, in Luce and Jessop, p. 31. Subsequent citations are incorporated in the text.

3 As Yolton, p. 77, argues, Berkeley holds that ideas must be perceivable. If 'grace' or ' $I$ ' can be called ideas, they must appear within experience, in some historical context.

4 See Hooker, pp. 266-269. See also Clark, p. 233; and Dancy, p. 146.

5 Berkeley seldom advances an original argument. His novelty as a philosopher lies in his capacity to place familiar arguments in new and unlikely contexts.

Consequently, he often argues by analogy, suggesting, for example, that the 
argument for the linguistic character of nature is 'similar' to the argument from design. See Hooker, pp. 262-3.

6 On Berkeley's use of Boerhaave and other chemists, see Tipton, pp. 160-161.

7 Richardson was an admirer of Berkeley's - an admirer who, as T.C. DuncanEaves and Ben D. Kimpel admit, understood at least 'the general tenor' of Berkeley's philosophy. See Duncan-Eaves and Kimpel, p. 571.QL

\section{Works Cited}

Berkeley, George. Alciphron: Or, The Minute Philosopher. The Works of George Berkeley. Ed. A.A. Luce and T.E. Jessop. London: Thomas Nelson, 1950. Vol. III.

Box, Mark A. The Suasive Art of David Hume. Princeton: Princeton UP, 1990.

Carr, Stephen Leo. 'The Rhetoric of Argument in Berkeley's Siris.' University of Toronto Quarterly 51 (1981): 47-60.

Clark, Stephen R.L. 'God Appointed Berkeley and the General Good,' in: Essays on Berkeley, ed. John Foster and Howard Robinson. Oxford: Clarendon, 1985. 233-253.

Cope, Kevin L. Criteria of Certainty: Truth and Judgement in the English Enlightenment. Lexington: UP of Kentucky, 1990.

Davie, Donald. 'Berkeley and the Style of Dialogue,' in: The English Mind, ed. Hugh Sykes Davies and George Watson. Cambridge: Cambridge UP, 1964. 90-106.

. 'Berkeley's Style in Siris.' Cambridge Journal 4 (1951): 427-433.

Dancy, Jonathan. Berkeley: An Introduction. Oxford: Blackwell, 1987.

Duncan-Evans, T.C., and Ben D. Kimpel. Samuel Richardson: A Biography. Oxford: Clarendon, 1971.

Ginsberg, Robert, ed. The Philosopher as Writer. Selinsgrove: Susquehanna UP, 1987.

Hooker, Michael. 'Berkeley's Argument from Design,' in: Berkeley: Critical and Interpretive Essays, ed. Colin M. Turbayne. Minneapolis: U of Minnesota P, 1982. 261-270.

Linnell, John. 'Berkeley's Siris.' Personalist 47 (1960): 11-22.

Raine, Kathleen. 'Berkeley, Blake and the New Age.' Thought 51 (1976): 356-377.

Richetti, John. Philosophical Writing. Cambridge: Harvard UP, 1983.

Tipton, I.C. 'The 'Philosopher by Fire' in Berkeley's Alciphron,' in: Berkeley: Critical and Interpretive Essays, ed. Colin M. Turbayne. 159-173.

Walmsley, Peter. The Rhetoric of Berkeley's Philosophy. Cambridge: CUP, 1990.

Yolton, John. Thinking Matter: Materialism in Eighteenth-Century Britain. Minneapolis: U of Minnesota P, 1983.

Young, Theodore. Completing Berkeley's Project. Boston: UP of America, 1985. 